\title{
A jogi személy jó hírnevének védelme az EUB és EJEB joggyakorlatán keresztül Nyikes Zita*
}

\begin{abstract}
Jelen tanulmány egy nagyobb ívü, a jogi személy jó hírnevét nemzetközi kitekintésben vizsgáló kutatás része, amelynek egyik részeredményét kívánja ismertetni. A természetes személyek jogainak védelme magától értetödő, bár, a jó hírnévhez való jog az alapvetö jogokhoz képest speciális, ugyanez a mesterségesen létrehozott jogi személyek esetében pedig már unikális kérdés. A vizsgálat elsōsorban arra irányult, hogy találunk-e jogi személyek jó hírnevét érintö eseteket az Európai Unió Bírósága (EUB), illetve az Emberi Jogok Európai Bírósága (EJEB) ügyei között, ha igen, milyen okokból merültek ezek fel, és milyen eredménnyel zárultak.
\end{abstract}

Kulcsszavak: joghatóság, jogi személy, jó hírnév, személyiségi jogok, EJEB, EUB, kártérítés, hirnévrontás, nyomtatott sajtó, digitális média, véleménynyilvánitás szabadsága, kommentek

Protecting the reputation of a legal person through the case law of the CJEU and ECtHR

This paper is part of a broader research which is dealing with the reputation of the legal persons on an international level. Implicitly, the protection of the natural persons's rights is evident. On the other hand, the protection of the law in cases of the legal persons is rather unique. The research aimed whether we can find any court cases related to reputation of the legal person among the cases of the Court of Justice of the European Union (CJEU) or the European Court of Human Rights (ECHR). If yes, what is behind the court cases and what were the bases of the disagreement between the parties. Along the way, during the different court cases of the CJEU and the ECHR there were several steps protecting the legal persons, similar to the natural persons, in terms of the reputation.

Keywords: scope of authority, legal persons, reputation, personality rights, ECHR, CJEU, compensations, denigration, print-based media, digital media, right to freedom of opinion and expression, comments

DOI: $10.32980 / M J S z .2021 .1 .957$

\section{Az EUB joggyakorlata}

jó hírnév védelme a nemzeti jogok feladata. ${ }^{1}$ Mérvadó uniós szabályok Q hiányában, a hírnévsértéssel kapcsolatos ügyek ezért joghatósági kérdésként

\footnotetext{
* PhD-hallgató, Miskolci Egyetem, Állam-és Jogtudományi Kar, Civilisztikai Tudományok Intézete, Kereskedelmi Jogi Intézeti Tanszék.

${ }^{1}$ Magyarországon a jogi személyek jó hírnevét alapvetően két törvény védi:

A Polgári Törvénykönyvről szóló 2013. évi V. törvény 2:45. § (2) bekezdése szerint: „A jóhírnév megsértését jelenti különösen, ha valaki más személyre vonatkozó és e személyt sértő, valótlan tényt állít vagy híresztel, vagy valós tényt hamis színben tüntet fel."

A jóhírnév védelme a természetes és a jogi személyeket egyaránt megilleti. A jogsértés tehát különösen akkor valósul meg, ha valaki más személyre sértő közlést tesz, a közlés tényállítást tartalmaz, és valótlant állít vagy híresztel, vagy a valóságot hamis színben tünteti fel.
}

A tisztességtelen piaci magatartás és a versenykorlátozás tilalmáról szóló 1996. évi LVII. törvény 3. § szerint: "Tilos valótlan tény állításával vagy híresztelésével, valamint valós tény hamis színben való 
jelennek meg az EUB előtt, kifejezetten akkor, ha több tagállam is érintett a jogsértéssel. AZ EUB a később ismertett egyik ügyben a joghatóságon kívül mégis foglalkozott a jogi személy jó hírnevének kérdésével is, amire az adott okot, hogy az érintett tagállamok egyikében a jogi személy ilyen irányú védelme nem szabályozott.

\subsection{A joghatóság kérdése}

1.1.1. Három hónap Párizsban. 1989-ben Fiona Shevill brit állampolgár három hónapot dolgozott Párizsban, és ki gondolta volna, hogy ez a három hónap alapozza majd meg azt az esetjogi döntést, amelyre később más esetek kapcsán is hivatkoztak, és amely a jogi személyek jó hírnevének védelme szempontjából is meghatározó lesz. A Shevill $v$. Press Alliance $S A$ ügy ${ }^{2}$ esetében a jó hírnév megsértése az írott sajtóban történő megjelenéshez köthető. Fiona Shevill brit állampolgár pert indított az Egyesült Királyságban rágalmazás miatt a francia Press Alliance SA ellen, amiért a kiadó a tulajdonában álló France Soir egyik cikkében azt állította valótlanul, hogy Fiona Shevill érintett egy nemzetközi kábítószer-hálózat működtetésében. Az eset a jogi személyek hírnévsértése szempontjából azért említendő, mert joghatósági kérdéseket tisztáz. A Bíróság megállapította, hogy a jóhírnév több szerződő államban közzétett sajtócikk révén megvalósuló megsértése esetén a sértett a kiadó ellen kártérítés iránti keresetet indíthat: vagy a jóhírnevet sértő tartalmat közzétevő kiadó letelepedési helye szerinti állam bírósága előtt amely bíróság a jóhírnév megsértéséből eredő teljes kár megtérítésének elrendelésére hatáskörrel rendelkezik -, vagy pedig bármely azon tagállam bírósága előtt, ahol a közzététel megvalósult, és ahol a sértett jóhírnevét állítólag megsértették - amely bíróság kizárólag az ebben az államban okozott kár elbírálására rendelkezik hatáskörrel („mmozaikszabály").

1.1.2. Szférák zenéje. A következő fontos állomás - amely még mindig a természetes személy jó hírnevéhez köthető, de abból a szempontból előrelépés, hogy már digitális felületen valósul meg a jogsértés -, két ügy összevonása során hozott döntés. Az egyik az eDate Advertising és társai ügy (C- 509/90) ${ }^{3}$ amelynek alapja, hogy az osztrák eDate Advertising GmbH elsősorban homoszexuális közönséget célzó internetes portálja folyamatosan tájékoztatást adott egy német állampolgárról, akit egy ismert német színész meggyilkolása miatt ítéltek életfogytig tartó szabadságvesztésre. A magát sértettnek érző és 2008-ban feltételes szabadlábra helyezett felperes egy német bírósághoz fordult, kérve, hogy az tiltsa el a kérdéses osztrák portált a róla szóló információk terjesztésétől Németország teljes területére kiterjedően, és kötelezze nem vagyoni kárának megtérítésére.

A másik ügyben (C-161/10. sz. ügy) a tribunal de grande instance de Paris (párizsi általános hatáskörű elsőfokú bíróság) előtt a francia színész Olivier Martinez és apja, Robert Martinez a magánéletük tiszteletben tartásához füződő joguk, valamint Olivier Martinez hírnevéhez füződő jogának megsértésére hivatkoztak. A sérelmet a

feltüntetésével, úgyszintén egyéb magatartással a versenytárs jó hírnevét vagy hitelképességét sérteni, illetőleg veszélyeztetni."

${ }^{2}$ C-68/93, https://eur-lex.europa.eu/legal-content/EN/TXT/?uri=CELEX:61993CJ0068

${ }^{3}$ https://curia.europa.eu/juris/liste.jsf?\&num=C-509/09 
www.sundaymirror.co.uk az Egyesült Királyságban szerkesztett internetes oldalon közzétett, angol nyelven íródott, 2008. február 3.-án kelt, francia nyelvre fordított "Kylie Minogue est de nouveau avec Olivier Martinez" (Kylie Minogue újra együtt Olivier Martinezzel) című cikk szövege okozta, amely részletezte találkozásukat. A felperesek tehát állampolgárságuk országában indították a pert, aminek oka elsősorban az volt, hogy francia nyelven is megjelent a cikk. A keresetet a francia Polgári Törvénykönyv megsértése miatt indították a Sunday Mirror brit lap honlapját szerkesztő, az angol jog hatálya alá tartozó MGN társaság ellen. E társaság azonban a francia bíróság hatáskörének hiányára hivatkozott.

A két üggyel kapcsolatban az EUB számos, előremutató megállapítást tett. A Shevill ügyben tett joghatósági megállapítások más tömegkommunikációs és távközlési eszközökre is érvényesek. Valamely tartalom internetes honlapon való közzététele azonban különbözik a nyomtatott sajtó területileg behatárolt közzétételétől, mivel föszabály szerint arra irányul, hogy az említett tartalom mindenütt jelen legyen. E tartalmat az egész világon nyomban letöltheti meghatározhatatlan számú internetfelhasználó, függetlenül attól, hogy közzétevőjének szándéka arra irányult-e, hogy azt a letelepedési helye szerinti tagállamon kívül is letöltsék, és a letöltések kívül esnek a hatókörén.

Az internet csökkenti „ahol a közzététel megvalósult" kritérium hasznosságát, mivel az interneten közétett tartalom főszabály szerint bárhol hozzáférhető. Továbbá valamely konkrét tagállam vonatkozásában müszakilag nem mindig lehetséges teljes bizonyossággal és hitelt érdemlően számszerüsíteni e terjesztést, és ennélfogva nem mindig lehetséges felmérni a kizárólag e tagállamban okozott kárt sem. Az interneten közzétett tartalom valamely személy személyiségi jogaira való kihatását azon hely szerinti bíróság tudja leginkább megítélni, ahol az állitólagos sértett érdekeinek központja található.

Ez általában a szokásos lakóhelyének felel meg, azonban olyan tagállamban is lehet, ahol e személy nem rendelkezik szokásos lakóhellyel, amennyiben más ténykörülmények, úgymint valamely szakmai tevékenység gyakorlása, az ezen állammal való különösen szoros kapcsolatra utalhatnak.

Összegezve, a polgári és kereskedelmi ügyekben a joghatóságról, valamint a határozatok elismeréséről és végrehajtásáról szóló, 2000. december 22-i 44/2001/EK tanácsi rendelet 5. cikkének 3. pontját úgy kell értelmezni, hogy a személyiségi jogok valamely internetes honlap tartalma általi állítólagos megsértése esetén a sértett személynek lehetősége van arra, hogy az okozott teljes kár megtérítése érdekében felelősség megállapítása iránti keresetet nyújtson be: vagy e tartalom közzétevőjének letelepedési helye szerinti tagállam bíróságához, vagy pedig azon tagállam bíróságához, ahol a sértett személy érdekeinek központja található. Emellett az érintett személy benyújthatja keresetét bármely olyan tagállam bíróságához is, amelynek a területén az interneten közzétett tartalom hozzáférhető, vagy hozzáférhető volt. $\mathrm{E}$ bíróságok kizárólag a tagállamuk területén okozott kár elbírálására rendelkeznek hatáskörrel.

1.2. Északról tör be a "fény" a jogi személy jó hírneve. A jogi személy sérelmére elkövetett hírnévsértés terén áttörést jelentett a Bolagsupplysningen OÜ 
Ingrid Ilsjan kontra Svensk Handel $A B$ ügy, ${ }^{4}$ ami interneten valósult meg. Maga az ítélet csak a joghatósági kérdésekkel foglalkozik, de a határozathoz fúzött észrevételek érintik a jogi személy személyhez füződő jogait és jó hírnevének védelmét.

A Bolagsupplysningen OÜ (felperes) Tallinban, Észtországban székhellyel rendelkező társaság, amely láthatóan Svédországban folytatja gazdasági tevékenysége legnagyobb részét. I. Ilsjan a felperes munkavállalója. A Svensk Handel AB svéd kereskedelmi szövetség (alperes) azzal a bejegyzéssel vette fel a felperest a weboldalán vezetett fekete listára, hogy a felperes "'csaló és szélhámos". A feketelistára történő felvételre adott válaszképpen közel 1000 hozzászólás érkezett a weboldal vitafórumára, köztük a felperessel és annak dolgozóival szembeni erőszakra való közvetlen felhívások. Az észt vállalkozás keresetet nyújtott be a bíróságnál a svéd szövetséggel szemben arra való hivatkozással, hogy a közzétett információk miatt sérült a jó hírneve. Arra kérte a svéd szövetséget, hogy az állításokat igazítsák helyre és a hozzászólásokat töröljék. Azt állította továbbá, hogy a hozzászólások és az állítások miatt kárt szenvedett el, melynek megtérítését követelte. A felperes és I. Ilsjan arra hivatkozott, hogy az alperes magatartása eredményeképpen kára keletkezett, mert a valótlan állítások közzététele folytán megbénult a felperes svédországi gazdasági tevékenysége.

Kérdésként merült fel, hogy az észt bíróságok megállapíthatták-e joghatóságukat a felperes „érdekeinek központja” alapján, amely különös joghatósági okot az EUB természetes személyek vonatkozásában már alkalmazta, jogi személyek tekintetében viszont nem. Az észt legfelsőbb bíróság által benyújtott előzetes döntéshozatal iránti kérelem tekintetében Michal Bobek fötanácsnok indítványa ${ }^{5}$ vetett fel új szempontokat. Friss és talán kritikusabb áttekintését javasolta az EUB korábbi ítélkezési gyakorlatának arra hivatkozva, hogy jelen ügyben jogi személy kéri az elsődlegesen az interneten hozzáférhetővé tett állítások helyreigazítását és eltávolítását. „„.... foglalkozni kell egy előzetes kérdéssel: a személyiségi jogok internetes megsértése tekintetében megkülönböztethetjük-e a természetes és jogi személyeket?"6 Ráirányította a figyelmet arra is, hogy a szóban forgó ügyben kétségkívül terjedelmes vita tárgyát képezi a kérdés, hogy a jogi személyekre is kiterjeszthető-e a személyiségi jogok, mint alapvető jogok védelme, és hogy rendelkeznek-e a jogi személyek személyiségi jogokkal. ${ }^{7}$ Michal Bobek fótanácsnok kifejtette, hogy számos tagállam jogában törvényen alapuló jogaik részeként védelmet élvez a jogi személyek jó hírneve. ${ }^{8}$

Michal Bobek fő́tanácsnok röviden áttekintette, ${ }^{9}$ hogy az EJEB fokozatosan kiterjesztette a jogi személyekre az alapvető jogok védelmét. Például a

\footnotetext{
${ }^{4}$ C-194/16. sz. ügy

${ }^{5}$ Michal Bobek fötanácsnok indítványa, 2017.

https://curia.europa.eu/juris/document/document.jsf?text=\&docid=192713\&pageIndex=0\&doclang= hu\&mode $=$ Ist\&dir $=\&$ occ $=$ first\&part $=1 \&$ cid $=4829106$

${ }^{6}$ Michal Bobek fötanácsnoki indítvány 35. pont.

7 Michal Bobek főtanácsnoki indítvány 37. pont.

${ }^{8}$ Michal Bobek főtanácsnoki indítvány 40 . pont.

${ }^{9}$ Michal Bobek főtanácsnoki indítvány 42 . pont.
} 
véleménynyilvánítás szabadsága, a lakás és levelezés tiszteletben tartásához való jog és a tisztességes tárgyaláshoz való jog tekintetében.

Michal Bobek úgy látta, hogy az uniós jog rendszerén belül az EUB is megerősítette, hogy a jogi személyek jogokat élveznek, mint tulajdonhoz való jog, a vállalkozás szabadsága, hatékony jogorvoslathoz való jog, költségmentességhez való jog, ártatlanság vélelme és különösen a védelemhez való jog. ${ }^{10}$ Összefoglalva pedig rámutatott arra, hogy az alapvető jogok jogi személyekre történő kiterjesztése mind az EJEB mind az EUB jogalkalmazásában fokozatosan és természetes módon történt. Michal Bobek szerint, a személyiségi jogokra tekinthetünk olyan eszközként is, amely más alapvető jogok hatékony védelmét szolgálja, nem pedig önmagáért van. A jogi személyek személyiségi jogainak védelme más jogokhoz is elvezet, mint amilyen például a tulajdonhoz való jog vagy a vállalkozás szabadsága. Ezt a logikát követve egy társaság jó hírnevének sérelme közvetlenül megvalósítja a társaság gazdasági jogainak sérelmét. A gazdasági jogok hatékony védelme érdekében védelemben kell részesíteni a személyhez füzódó jogaikat is. ${ }^{11}$

A joghatóság tekintetében a Date Advertising és társai ítéletben megfogalmazottak az irányadóak, de az érdekek központját a jogi személy szemszögéből kell vizsgálni. Olyan gazdasági tevékenységet végző jogi személy esetében, mint az alapeljárás felperese, az érdekek központja az a hely, ahol az üzleti jóhírneve a leginkább megalapozott. Így azt, azt azon hely alapján kell meghatározni, ahol a gazdasági tevékenységének túlnyomó részét végzi. Valamely jogi személy érdekeinek központja megegyezhet a létesítő okirat szerinti székhelyével is, ha itt gyakorolja tevékenységeinek összességét vagy túlnyomó részét, és ha az általa ott élvezett jóhírnév ennek következtében jelentősebb, mint bármely más tagállamban.

A jogi személy, amelynek a személyhez füződő jogait megsértették az állitások helyreigazítása, a hozzászólások eltávolítására való kötelezés és a valótlan állítások interneten történő közzétételével okozott vagyoni kár megtérítése iránt keresetet indíthat az általa elszenvedett teljes kár tekintetében azon tagállam bíróságai előtt, ahol érdekeinek központja található.

1.3. Versenyjogsértés kontra hírnévsértés? A jogi személyek jó hírnevének védelme alapvetően a nemzeti jogok feladata, így adekvát uniós szabályokkal nem talákozhatunk. Emiatt volt érdekes az alábbi eset, amelyben, egy kartell ügyben érintett vállalkozás harcolt azért, hogy a versenyjogsértést megállapító és széles körben megjelenő határozatban neve, valamint a rá utaló részek ne jelenjenek meg, miután vele szemben megszüntették az eljárást. A jó hírnév védelme uniós szabályozás hiányában egyrészről közvetett módon és a vállalkozás érveinek egyikeként jelent csak meg, másrészről izgalmas, hogy az EUB erre reagálva, milyen megközelítést alkalmazott.

A 2007-ben ítélettel zárult Pergan Hilfsstoffe für industrielle Prozesse $\mathrm{GmbH}$ kontra az Európai Közösségek Bizottsága ügyben, a felperes kérte egy versenysértést megállapító határozatból a rá vonatkozó adatok törlését, arra hivatkozással, hogy azok - többek között - jó hírnevét sérthetik.

\footnotetext{
${ }^{10}$ Michal Bobek főtanácsnoki indítvány 43. pont.

${ }^{11}$ Michal Bobek főtanácsnoki indítvány 47-49. pont.
} 
Az ügy előzménye az volt, hogy 2002-ben a Bizottság vizsgálatot indított a szerves peroxidok európai elóállítóival szemben - értve ezalatt az AKZO-csoportot, az Atofina SA-t, és a Degussa UK Holdings Ltd által irányított társaságot, a Peroxid Chemie-t, a ACTreuhand-ot, a Peróxidos Orgánicos-t, továbbá a felperest kartellekben, egy főkartellben és több regionális kartellben való részvétel miatt a szerves peroxidok bizonyos piacain.

A Bizottság határozatában (ún. proxid határozat) bírságot szabott ki az Atofinara, a Peroxid Chemie-re, a ACTreuhandra, a Peróxidos Orgánicosra és a Degussa UK-re kartellezés miatt. E határozat címzettjei a fenti társaságok voltak, a felperes azonban nem. A Bizottság azt állapította meg ugyanis, hogy a felperes nem vett részt a főkartellben, de az 1993-tól 1996-ig terjedő időszakban érintett volt a versenysértésekben, az Atochem/Atofinával és a Peroxid Chemie-vel való versenyellenes célú találkozókon és kapcsolatokon keresztül, valamint érzékeny üzleti adatok utóbbiakkal való cseréjén keresztül, ez a magatartása viszont elévült.

A peroxid-határozat a rendelkező részében nem tartalmazott utalást a felperesre, azonban annak több preambulum-bekezdése utalt rá, az alábbiak szerint:

„Ami a [felperest] illeti, a Bizottság megállapítja, hogy nem bizonyítható e vállalkozásnak az 1997. január 31., az elévülés szempontjából releváns időpont utáni egyedüli és folyamatos jogsértésben való részvétele. [...]"

„„..... A jelen határozatot nem a [felpereshez] intézték, mivel a [felperes] 1997. január 31-e utáni részvétele nem volt bizonyítható."

A Bizottság 2004. február 18-i levelével küldte meg a felperesnek a peroxidhatározat egy példányát, tájékoztatva a felperest, hogy közzé kívánja tenni a peroxid-határozat nem bizalmas változatát, és felhívta, hogy jelölje meg azon esetleges részeket, amelyekről úgy gondolja, hogy üzleti titkokat vagy más bizalmas információkat tartalmaznak (ún. szolgálati titok). 2004. április 13-i levelében a felperes kérte, hogy a peroxid-határozatból távolítsák el a nevét. Az ideiglenes változat ennek megfelelóen jelent meg a Bizottság internetes honlapján. A felperes kérte a ráutaló részek törlését a végleges határozatból is. 2004. június 28-án a Bizottság elutasította felperes kérelmét. Közölte, hogy a határozatban a felperes általi versenysértésre következtetett, elévülési ok miatt mégsem volt lehetséges rá büntetést kiszabni. A felperes, élve jogaival, az ún. meghallgatási tisztviselőhöz fordult, azt kérte, hogy távolítson el a peroxid-határozat közzétételre szánt végleges változatából minden felperesre vonatkozó utalást. Kérelme alátámasztásaként a felperes, többek között, azt állította, hogy ezen utalások jó hírnevét sértenék a piacon. A meghallgatási tisztviselő elutasította a kérelmet, a jó hírnév megsértése tekintetében megjegyezte, hogy a felperes jó hírnevének esetleges sérelme a határozat közzététele miatt, megfelelő következménye a vitatott kartellekben való felperesi érintettségnek. A Bizottság a versenyjogi főhatóság internetes honlapján közzétette a peroxid-határozat nem bizalmas változatát, amely tartalmazta a felperesre vonatkozó utalásokat, és amely miatt felperes elóterjesztette a keresetet.

A Bíróság úgy ítélte meg, hogy amennyiben a Bizottságnak a valamely vállalkozás által elkövetett jogsértésre vonatkozó megállapításai sérthetik az ártatlanság vélelme elvének alkalmazását, ezeket föszabály szerint a nyilvánosság tekintetében bizalmasnak és következésképpen jellegüknél fogva a szolgálati titok körébe 
tartozónak kell tekinteni. Ezen elv többek között annak szükségességéből következik, hogy az érintett személy jó hírnevét és méltóságát mindaddig tiszteletben tartsák, ameddig nem ítélték el jogerösen.

Úgy kell ezért tekinteni, hogy a vitatott utalások jellegüknél fogva a szolgálati titok körébe tartozó információknak minösülnek. Meg kell állapítani, hogy ilyen körülmények között a felperes jogos érdekét megelőző, a vitatott utalások közzétételéhez füződő közérdek hiányzik.

A Bíróság tehát a felperesnek adott igazat, és jó hírnevének védelme érdekében, a határozat rá vonatkozó részeit a szolgálati titok körébe vonta, kinyilvánítva azt is, hogy jelen esetben hiányzik az a közérdek, amely indokolná a vitatott részek közzétételét.

\section{Az EJEB döntései}

Az EJEB előtt az Emberi Jogok Európai Egyezménye (EJEE) 8. cikkének és 10. cikkének megsértése okán indult ügyekben merült fel a jogi személy jó hírneve. Az esetek többségében a jogsértést elkövetők fordultak az EJEB-hez a véleménynyilvánítás szabadságához füződő joguk (10. cikk) megsértésére hivatkozva, mert a nemzeti bíróságok marasztalták őket a jogi személlyel szemben. Ritka kivétel az egyik ügy, amelyben maga a jogi személy kért jogsegélyt az EJEBtől jó hírnevének megsértése miatt, a 8. cikkre hivatkozva.

2.1. A Fayed ügy. Az ügy csak közvetett módon érinti a jogi személyek személyiségi jogainak elismerését. ${ }^{1213} \mathrm{Az}$ évekig húzódó eset hátterében az állt, hogy a Fayed fivérek 1985-ben megszerezték a House of Fraser céget. Később a cég megszerzésének körülményeit feltáró hivatalos jelentés azt állapította meg, hogy a Fayed fivérek nem voltak őszinték, amikor bemutatták a vagyoni viszonyaikat, az üzleti érdekeltségeiket és a cégvásárlás körülményeit. A cég megszerzésének körülményeit feltáró jelentés nyilvánosságra került és a tartalmát széles körben publikálták, többek között nyomatott médiafelületeken. ${ }^{14} \mathrm{Az}$ Observer napilap egy 16 oldalas hétköznapi külön kiadványt szentelt a jelentésnek, amelyekhez kommenteket is füztek. A jelentést egyébként nem hivatalos módon szerezte meg a napilap. ${ }^{15}$ A Fayed fivérek hírnévsértés miatt pereket indítottak Angliában, majd az EJEB-hez fordultak, a kérelmezők között nem szerepelt az érintett, multinacionális gazdasági társaság. Az EJEB azt állapította meg, hogy a hatóságok a hivatalos nyomozás eredményeit tárták fel, a jelentésben sem tartalmilag, sem formailag nem

\footnotetext{
12 Fayed v United Kingdom Series A, No. 294-B Application No. 17101/90 Before the European Court of Human Rights 21 September 1994, https://www.ucpi.org.uk/wp-content/uploads/2017/02/Fayed-vUnited-Kingdom-1994-18-EHRR-393.pdf

${ }_{13}$ https://hudoc.echr.coe.int/eng\#\{"itemid":["001-57890"]\}

14 Például az alábbi linken is elérhető egy ilyen cikk: https://www.independent.co.uk/news/world/lawreport-fayeds-rights-not-violated-by-dti-study-fayed-v-the-united-kingdom-european-court-of1441327.html

15 25. pont, https://www.ucpi.org.uk/wp-content/uploads/2017/02/Fayed-v-United-Kingdom-1994-18EHRR-393.pdf
} 
minősítettek, semmilyen büntetőjogi vagy polgári jogi felelősséget nem állítottak, a Fayed testvérek jó hírneve nem sérült. Az ügy kapcsán az EJEB kitért arra, hogy az a tény, hogy az egyik fél multinacionális társaság volt, nem foszthatja meg őt attól a jogától, hogy megvédje magát a jó hírnevét sértő állításokkal szemben.

2.2. A rossz bornak sem kell a cégér? 2008. január 2-án a kérelmező, egy újságíró, cikket közölt egy országos napilap „Vélemény" rovatában. A cikk tárgya egy jól ismert magyar borfajta, a T. Zrt. - egy állami tulajdonban álló gazdasági társaság - termékének minősége volt, amely termék a kérelmező szerint rossz, ezt vulgárisan is kifejezte, népszerüsége a magyar fogyasztók körében indokolatlan. A T. Zrt. nem magánjogi úton érvényesítette igényét, hanem büntető feljelentést tett a kérelmező ellen. A magyar bíróságok rágalmazás miatt elítélték a kérelmezőt, megállapítva, hogy a kérelmező cikkében kifejezett kritika túlment az újságírói vélemény határán, és a szóban forgó borfajta termelője jó hírnevének megsértésére alkalmas tényállításnak minősült.

A kérelmező a 10. cikk megsértése miatt fordult az EJEB-hez. Érintett cikk szövege: „1. Mindenkinek joga van a véleménynyilvánítás szabadságához. Ez a jog magában foglalja a véleményalkotás szabadságát és az információk, eszmék megismerésének és közlésének szabadságát országhatárokra tekintet nélkül és anélkül, hogy ebbe hatósági szerv beavatkozhasson.

2. E kötelezettségekkel és felelősséggel együtt járó szabadságok gyakorlása a törvényben meghatározott, olyan alakszerüségeknek, feltételeknek, korlátozásoknak vagy szankcióknak vethető alá, amelyek szükséges intézkedéseknek minősülnek egy demokratikus társadalomban a ... mások jó hírneve vagy jogai védelme ... céljából."

A Bíróság vizsgálta, hogy a kérelmező számára a 10. cikkben biztosított jogokba történt beavatkozás „törvényben elöírt" volt-e, törvényes célt vagy célokat szolgálte, és "egy demokratikus társadalomban szükséges" volt-e azon célok eléréséhez. A Bíróság rögzítette, hogy a panaszolt intézkedés törvényes volt, a Büntető Törvénykönyvön alapult. A Bíróság elfogadta, hogy a beavatkozás törvényes célt szolgált, nevezetesen mások jó hírnevének vagy jogainak védelmét.

A Bíróság észrevételezte, hogy a kifogásolt büntetőjogi vádakat egy olyan gazdasági társaság emelte, amelynek vitathatatlanul joga van arra, hogy rágalmazó állításokkal szemben megvédelmezze magát, fennáll egy, a gazdasági társaságok kereskedelmi sikerének és életképességének védelméhez füződö, a részvényesek, a munkavállalók és a szélesebb gazdaság javát is szolgáló, a véleménynyilvánitás szabadságával versengő érdek.

Különbség van azonban egy gazdasági társaság kereskedelmi jó hírnévhez füződő érdeke, valamint az egyén - társadalmi státuszt érintő - jó hírneve között. Míg ez utóbbi hatással lehet a méltóságra, a Bíróság számára a kereskedelmi jó hírnévhez füződő érdek nélkülözi ezt az erkölcsi dimenziót. A jelen kérelemben a kockán forgó, jó hírnévvel kapcsolatos érdek egy állami tulajdonban álló gazdasági társaság érdeke; ilyen módon ez kereskedelmi érdek, melynek az erkölcsi karakter szempontjából nincs relevanciája.

Az ügy tárgya azonban nem becsületsértő tényállítás, hanem - amint azt a hazai bíróságok megállapították - értékitélet vagy vélemény. A szóban forgó publikáció a kormányzati gazdaságpolitikák és a fogyasztói attitűdök összefüggésében a 
gazdasági társaság szatirikus denunciálását valósította meg. A fenti tényeket figyelembe véve a Bíróság úgy találta, hogy a kérelmező elsődleges célja az állami tulajdonlás hátrányaira történő figyelemfelhívás volt, nem pedig $a z$, hogy a gazdasági társaság által előallított termékek minőségének rossz hírét keltse az olvasók tudatában. A vélemény kifejezésére a nemzeti értékek védelmével, valamint a magánvállalkozásokkal és a külföldi befektetésekkel kapcsolatos kormányzati politikákra hivatkozással került sor. Ilyen módon közérdeküüggyel volt kapcsolatos. A Bíróság úgy vélte: a hazai bíróságok nem vették figyelembe azt a tényt, hogy a sajtótól elvárható a közérdekü ügyekkel kapcsolatos információk és eszmék közlése, és ennek során akár bizonyos fokú túlzás vagy akár provokáció használatához, vagy - más szóval -, némileg mértéktelen nyilatkozatok megtételéhez is folyamodhat. A Bíróság megjegyzi, hogy a vulgáris kifejezések használata önmagában nem perdöntó valamely sértó kifejezés megitélésekor, mivel az pusztán stilisztikai célokat is szolgálhat. A Bíróság számára a stílus - a kifejezés formájaként - a kommunikáció részét képezi, s ilyenként a kifejezés tartalmával együtt védelemben részesül.

A Bíróság úgy találta, hogy a hazai hatóságok nem állapították meg meggyőzó módon a beavatkozás szükségességét, az Egyezmény 10. cikkét megsértették. ${ }^{16}$

2.3. Csánics kontra Magyarország ügy. A 2009-es ügy alapja a Csánics Sándor Értékszállítási és Örzésvédelmi Dolgozók Szakszervezetének elnöke által Magyarország ellen benyújtott kérelem (12188/06 sz.). A kérelmező, aki szakszervezeti vezető, azt állította, hogy a hazai hatóságok határozatai megsértették az Egyezmény 10. Cikke szerinti véleménynyilvánítás szabadságához füződő jogát akkor, amikor egy, a szakszervezet által szervezett tüntetéssel kapcsolatos interjúban tett kijelentéseinek helyreigazítására kötelezték.

2002. december 14-én a Színes Mai Lap címü napilap cikket közölt. A lap a kérelmezőt is meginterjúvolta, aki az alábbi nyilatkozatokat tette: ( )." A másik ok [amiért demonstrációt tartunk], hogy 2500 dolgozó ne veszítse el a megélhetését, ne egy olyan cég legyen $D$... utódja, amely lábbal tiporja az alkotmányos és munkajogokat (...). Az embertelen vezetési stílus miatt nem volt maradásuk egy olyan helyen, ahol "lebünözőzték" őket. Mi majd ötven esetben bírósághoz is fordultunk ezért."

A cikkben érintett $G$ cég és vezető tisztségviselője is pert indított jó hírnevének megsértése miatt. A kérelmező ezzel szemben a szabad véleménynyilvánítás jogára hivatkozott. A magyar bíróságok marasztalták a kérelmezőt, arra hivatkozva, hogy a véleménynyilvánítás szabadságához füződő jog nem korlátlan, és nem sértheti mások személyhez füződő jogait, a kérelmezői nyilatkozatok indokolatlanul sértőek, támadók és nyersek voltak, $\mathrm{s}$ értékítélet tartalmuktól függetlenül sértették a felperest. A kérelmező arra hivatkozott, hogy a magyar bíróságok megsértették az Egyezmény 10. Cikke szerinti véleménynyilvánítás szabadságához való jogát.

A Bíróság megállapította, hogy a beavatkozás, azaz a véleménynyilvánítás korlátozása törvényben meghatározott okból történt (magyar Ptk.), a panaszolt intézkedés mások jogai védelmének törvényes célját szolgálta. Kifogásolra viszont azt, hogy a magyar bíróságok szerint a kérelmező érintett nyilatkozatai egyaránt

${ }^{16}$ 23954/10. sz. kérelem https://tasz.hu/files/tasz/imce/uj_kontra_magyarorszag_hun.pdf 
tényállításnak minősülnek. A Bíróság szerint, különbséget kell tenni a tényállítások és az értékítéletek között abban a tekintetben, hogy míg a tények fennállása bizonyítható, addig az értékítéletek valóságtartalma nem bizonyitható.

A Bíróság szerint a jelen ügy két egymással összefüggő állítást érint. Az elsőt illetően - nevezetesen, hogy a G. társaságban a vezetés embertelen magatartása miatt lábbal tiporták a munkavállalók jogait - a Bíróság úgy vélte, hogy a kérelmező általában értékelte a G. társaság magatartását, $\mathrm{s}$ nyilatkozata értékítéletnek minősült. A másik állítást - nevezetesen, hogy a kérelmező szerint a G. társaság őt és kollégáit bűnözőnek nevezte - a Bíróság, a magyar bíróságokhoz hasonlóan ténybelinek tekintette. A Bíróság úgy vélte, hogy az ilyen nyilatkozatok, legalább részben, bizonyíthatóak. Következésképpen a Bíróság úgy vélte, hogy a hazai bíróságoknak lehetővé kellett volna tenniük a kérelmező számára, hogy nyilatkozatait alátámassza. Elvileg lehetőséget kell biztosítani arra, hogy igaz nyilatkozatokat nyilvánosan lehessen tenni, függetlenül azok hangvételétől, vagy az érintettekre gyakorolt negatív következményeitől.

A Bíróság észrevételezte, hogy a kérelmező a kifogásolt nyilatkozatokat közérdekü kérdésekkel kapcsolatos vitában, nevezetesen egy kollektív munkavita során tette. A Bíróság tisztában volt azzal a ténnyel, hogy az ilyen viták hangvétele a tét miatt gyakran heves. A Bíróság úgy vélte, hogy ezek a viták a 10. Cikk alapján magas szintü védelmet igényelnek, mivel a munkavállalók legfontosabb érdekeit érintik. A Bíróság úgy ítélte meg, hogy a kérelmező, aki szakszervezeti vezető, munkaügyi vitákban megszokott módon fogalmazta meg nyilatkozatait. Összegzésképpen megállapította, hogy a hazai bíróságok nem találták meg a megfelelő egyensúlyt a kérelmező véleménynyilvánitási szabadságának védelmére irányuló szükségesség, valamint a felperes jogainak és jó hírnevének védelmére irányuló szükségesség között. Következésképpen az Egyezmény 10. Cikkét megsértették. ${ }^{17}$

2.4. Véleménynyilvánítás kontra hírnévsértés ${ }^{18} \mathrm{~A}$ kérelmező a Magyar Tartalomszolgáltatók Egyesülete (MTE) és az Index.hu Zrt. A tényállás idején mindkét kérelmező engedélyezte a hírportáljaikon megjelenő olvasói kommenteket. 2010. február 5-én az MTE "Újabb etikátlan üzleti magatartás a neten" címmel véleményt tett közzé két ingatlan témájú weboldalról, amelyeknek ugyanaz a társaság a müködtetője. A vélemény szerint a két weboldal eredetileg harminc napig ingyenes hirdetési szolgáltatást nyújtott a felhasználóknak. A harminc napos díjmentes időszak lejáratát követően a szolgáltatás díjkötelessé vált, a felhasználók azonban erről nem kaptak előzetes értesítést. Ez azért volt lehetséges, mert a weboldalra való regisztráláskor a felhasználók elfogadták a felhasználási feltételeket,

\footnotetext{
17 12188/06. sz. kérelem

file://C:/Users/Judit/AppData/Local/Packages/Microsoft.MicrosoftEdge_8wekyb3d8bbwe/TempState/ Downloads/CASE\%200F\%20CSANICS\%20v.\%20HUNGARY\%20-

\%20[Hungarian\%20Translation] \%20by\%20the\%20Hungarian\%20Ministry\%20of\%20Justice\%20(1). pdf

18 22947/13. sz. kérelem

file:///G:/fogyvéd\%20és\%20versenyjog/versenyjog/hírnévsértés/CASE\%200F\%20MAGYAR\%20TART ALOMSZOLGALTAT.pdf
} 
melyek értelmében a szolgáltató egyoldalúan módosíthatta a felhasználási feltételeket. A vélemény kitért arra, hogy a szolgáltató csak akkor távolította el az elavult hirdetéseket és személyes adatokat a weboldalról, ha az esedékes díjakat megfizették. A vélemény megállapította, hogy a szolgáltató magatartása etikátlan és félrevezető volt. A véleményre álnéven közölt felhasználói kommentekben is reagáltak, amelyek közönséges kifejezéseket is tartalmaztak.

Az Index fogyasztóvédelmi blogja szintén írt a véleményről, a vélemény teljes szövegét közzétéve. Az Index közzétette az álnéven reagáló felhasználói hozzászólásokat is. Az érintett weboldalakat működtető társaság hírnévsértés miatt indított keresetet. A bírósági keresetről értesülvén a kérelmezők eltávolították a vitatott hozzászólásokat. A magyar bíróságok marasztalták a kérelmezőket, illetve megállapították felelősségüket - vitatva, hogy kérelmezők közvetítő szolgáltatók voltak csupán - a sértő vélemény és kommentek közzétételéért, amelyek alkalmasak voltak a felperes jó hírnevének megsértésére. A kérelmezők 2013. január 3-án alkotmányjogi panasszal éltek, lényegében vitatva a bíróságnak azt a döntését, amely a kommentek tartalmáért őket tette felelőssé, ezáltal - álláspontjuk szerint a véleménynyilvánítási szabadságukban alaptalanul korlátozta őket. $A z$ Alkotmánybíróság a panaszt 19/2014. (V.30.) AB határozatában elutasította. A kérelmezők az Egyezmény 10. cikkében előírt véleménynyilvánítás szabadság megsértése miatt indították az eljárást, ${ }^{19}$ amely során az EJEB az internetes hírportálokat üzemeltetők jogi felelősségét is taglalta a közzétett véleményekért, kommentekért. ${ }^{20} \mathrm{~A}$ Bíróság hangsúlyozta, hogy a jó hírnév védelmének jogát az Egyezmény 8 . cikke védi, ${ }^{21}$ a magán- és családi élet tiszteletben tartásához való jog részeként. ${ }^{22}$

19 „1. Mindenkinek joga van a véleménynyilvánítás szabadságához. Ez a jog magában foglalja a véleményalkotás szabadságát és az információk, eszmék megismerésének és közlésének szabadságát országhatárokra tekintet nélkül és anélkül, hogy ebbe hatósági szerv beavatkozhasson. Ez a cikk nem akadályozza, hogy az államok a rádió, televízió vagy mozgókép gazdasági társaságok működését engedélyezéshez kössék.

2. E kötelezettségekkel és felelősséggel együtt járó szabadságok gyakorlása a törvényben meghatározott, olyan alakszerűségeknek, feltételeknek, korlátozásoknak vagy szankcióknak vethető alá, amelyek szükséges intézkedéseknek minősülnek egy demokratikus társadalomban a nemzetbiztonság, a területi sértetlenség, a közbiztonság, a zavargás vagy bűnözés megelőzése, a közegészség vagy az erkölcsök védelme, mások jó hírneve vagy jogai védelme, a bizalmas értesülés közlésének megakadályozása vagy a bíróságok tekintélyének és pártatlanságának fenntartása céljából."

${ }^{20} \mathrm{E}$ felelősségi kérdésekkel is foglalkozik részletesen Koltay András: „Az internetes kapuőrök és az Emberi Jogok Európai Egyezményének 10. cikke: a sajtószabadság új alanyai" c. tanulmánya 137-138. Államés Jogtudoány, 2017. 4. szám, 129-140

https://jog.tk.hu/uploads/files/2017-04-AJT-teljes.pdf

${ }^{21}$ EJEE 8. cikk - Magán- és családi élet tiszteletben tartásához való jog

1. Mindenkinek joga van arra, hogy magán- és családi életét, lakását és levelezését tiszteletben tartsák.

2. E jog gyakorlásába hatóság csak a törvényben meghatározott, olyan esetekben avatkozhat be, amikor az egy demokratikus társadalomban a nemzetbiztonság, a közbiztonság vagy az ország gazdasági jóléte érdekében, zavargás vagy bűncselekmény megelőzése, a közegészség vagy az erkölcsök védelme, avagy mások jogainak és szabadságainak védelme érdekében szükséges.

${ }^{22}$ A Bíróság ítélkezési gyakorlatának fejlődése során, több ügy eredményeként, a Bíróság a hírnév védelméhez való jogot az egyezmény 8. cikke által garantált magánélethez való jog egyik aspektusaként értékelte. 
A Bíróságnak, amikor a véleménynyilvánítási szabadságba való, a „mások jó hírnevének és jogainak védelmére" végzett beavatkozás szükségszerüségét vizsgálja, meg kell győződnie arról, hogy a nemzeti hatóságok megfelelő egyensúlyt alakítottak-e ki e két, az Egyezmény által védett - és olykor egymással ütközó érték között, nevezetesen egyrészröl a 10. cikk által védett véleménynyilvánítási szabadság, másrészröl a 8. cikkben rögzített magánélethez való jog között.

A Bíróság megállapította, hogy - lényegét tekintve - a 8. és 10. cikkek által szavatolt jogok azonos tiszteletet érdemelnek. A Bíróság már korábbi alkalmak során meghatározta azokat a vonatkozó feltételeket, amelyek az összemérés során alkalmazandók, ezek közül különösen jelentősek: hozzájárulás közérdekű vitához, a jelentés tárgya, az érintett személy előzetes magatartása, a közzététel tartalma, formája és következményei, valamint az újságírókra vagy kiadókra kirótt büntetés súlya. A Bíróság ebben az ügyben is vizsgálta a beavatkozás törvényi alapját és célját, amelyet helyénvalónak talált, illetve azt, hogy az "szükséges volt-e demokratikus társadalomban".

A Bíróság megállapította, hogy az alapul szolgáló cikk két nagy ingatlanszakmai weboldal - ügyfeleire nézve félrevezetőnek és sérelmesnek ítélt - üzleti gyakorlatára vonatkozott, ebből fakadóan közérdek indokolta, hogy helyt adjanak egy, sok fogyasztót és internethasználót érintő, információcserét biztosító, nyilvános ügy vitájának. A szóban forgó magatartás már korábban számos panaszt eredményezett fogyasztóvédelmi testületeknél, továbbá számos eljárás indult az érintett társaság ellen. A cikk nem tekinthető tényalapot nélkülöző vagy indokolatlanul sértő megjegyzéseket kiváltó publikációnak. A Bíróság megítélése szerint jelen esetben értékítéletekről vagy véleményekről van szó. Tulajdonképpen egy üzleti magatartást ítéltek el, és ezeket részben befolyásolta a kommentelók személyes frusztrációja, mivel becsapta őket a szóban forgó társaság. Valójában a megjegyzéseket meggondolatlan reagálásnak lehet tekinteni. A kommentekben használt kifejezések sértő́ek voltak, az egyik kifejezetten közönséges volt. Azonban önmagában a közönséges kifejezések használata nem meghatározó valamely sértő véleménynyilvánítás értékelésében. A Bíróság felfogása szerint a stílus, mint kifejezési forma a kommunikáció részét képezi, és mint ilyen, a kifejezés tartalmával együtt védelmet élvez (lásd a fent idézett Uj kontra Magyarország ügy). A Bíróság felfogása szerint bár a kommentekben használt kifejezések egy alacsony stílusréteghez tartoznak, az internetes portálokon zajló kommunikációban gyakran előfordulnak, amely megfontolás az ilyen kifejezéseknek tulajdonítható hatást csökkentheti.

A kommentek következményeit is meg kell vizsgálni. A cikk és a vitatott kommentek közzétételének időpontjában már zajlottak vizsgálatok a felperes társaság üzleti magatartása kapcsán. Ennek tükrében a Bíróság nincsen meggyőződve arról, hogy a szóban forgó kommentek az érintett fogyasztók attitű́djére nézve bármely további jelentős hatással lehettek volna. A magyar bíróságok nem értékelték, hogy a kommentek elérték-e a komolyság kelló szintjét és hogy oly módon jelentek-e meg, amely ténylegesen sérthette egy jogi személy szakmai jó hírnevét. A Bíróság megállapította az Egyezmény 10. cikkének megsértését. 
2.5. Firma EDV v. Germany ügy ${ }^{23}$ A kérelmező gazdasági társaság egy szoftver vállalkozás volt, amely a német orvosok által széles körben használt adatbázisokhoz biztosított szoftvert és ügyfélszolgálatot. 1997. május 16-án az Medical Tribune, az orvosi szakemberek szakfolyóirata cikket tett közzé, amely figyelmeztetett egy technikai biztonsági adatszivárgás ehetőségére és a Firma EDV-t "Christusbetrieb" ként („Krisztus társasága”) tárta fel, amely szorosan kötődik az "Universelles Leben” nevü vallási közösséghez. Azt állította, hogy bár az Universelles Leben hivatalosan nem irányította a Firma EDV-t, ezt informális eszközökkel tette, mivel vallási meggyőződésük szerint minden alkalmazott, valamint a vezetőség kapcsolatban állt az Universelles Leben-nel. Erre a Bajorországi Evangélikus-Lutheránus Egyház képviselője kiadott egy sajtóközleményt „Biztonsági rés az orvosi praxisok szoftvereiben - A betegek adatai elérhetőek az Univerzális Élet pszicho-szekta számára" címmel. A közlemény arra figyelmeztetett, hogy "elképzelhető veszélye" van annak, hogy a társaság visszaélhet a betegek adataihoz való hozzáféréssel, és a vallási közösség céljai érdekében használhatja fel azokat.

A kérdés később a sajtóban is megjelent, ezt követően a sajtóbeli kritikákra hivatkozva felmondták a kérelmezőnek a szoftver forgalmazására és az ügyfélszolgálat nyújtására vonatkozó szerződését. Miután ezzel elvesztette fó bevételi forrását, a társaság megszüntette tevékenységét 1997. 12. 31.-ével. A kérelmező eljárást indított a hazai bíróságok előtt. Mindhárom fokon pert veszetett.

A Firma EDV az ügyet az EJEB elé terjesztette, hivatkozva az EJEE 8. és 9. cikkére, azt kifogásolva, hogy alkalmazottai és vezetőségének vallási hovatartozásának feltárásával megbízhatósága megkérdőjeleződött, ezen okok miatt a bajor protestáns-evangélikus egyház megrontotta hírnevét és tönkretette gazdasági tevékenységét.

Az EJEB számára az volt a fó kérdés, hogy a 8. cikk a "magánélet" részében alkalmazható-e egy jogi személyre, például a Firma EDV-re, aki a jóhírnévhez való jogának megsértésére panaszkodik. Az EJEB korábbi határozataiban megállapította, hogy a 8. cikk védelme felöleli egy jogi személy üzlethelyiségeit (a lakás tág fogalommeghatározása), az üzleti levelezését (a magán/evelezés meghatározásába), továbbá, hogy a társaság jó hírnevének védelme lehet az egyezmény 10. cikke (2) bekezdése szerinti korlátozás legitim célja (Heinisch v. Germany ügy, Application no. 28274/08). ${ }^{24}$

\footnotetext{
${ }^{23}$ 32783/08., 2014. szeptember

${ }^{24} \mathrm{Az}$ ügyben egy állami tulajdonban lévő társaság, aki idősek gondozásával foglalkozott volt érintett. Az egyik alkalmazottja büntető feljelentést tett ellene, illetve szórólapokat osztogatott, amelyben lejáratta a munkáltatóját. A feljelentés és a szórólap szerint, a munkáltató nem kielégítően végezte az idősek ápolását, veszélyeztette azokat és csalt. A munkáltató azonnali hatállyal felmondott az ápolónőnek. $A z$ ápolónő munkaügyi pert lezdeményezett a munkáltatóval szemben, amely pereket valamennyi fórumon elveszítette. A felmondás indokaként hangzott el, hogy a munkavállaló magatartásával, alaptalan vádjával és röplapjaival, megsértette a munkáltató jó hírnevét. A Heinisch nevú ápolónő munkavállaló az EJEB-hez fordult azzal, hogy a német bíróságok megsértették a véleménynyilvánítási szabadságát. Az eljárás során az EJEB megállapította az EJEE 10 cikkének megsértését. Az ügy során behatóbban vizsgálta az állami tulajdonban álló munkáltató jó hírnévhez való jogát és annak sérelmét.

A Bíróság úgy vélte, hogy a kérelmező büntető́jogi panaszainak alapjául szolgáló állítások, különösen azok, amelyek csalás vádjait tartalmazzák, minden bizonnyal sértették a Vivante üzleti hírnevét és kereskedelmi érdekeit. Ebben az összefüggésben kiemelte, hogy a vállalatokat megilleti a kereskedelmi
} 
A Bíróság úgy ítélte meg, hogy a jelen kereset alkalmazásában nyitva hagyható azon kérdés, hogy a jogi személy jó hírneve a 8 . cikk (1) bekezdése szerinti magánélet fogalmába tartozik-e. Tekintettel a már korábbi ítéletekre, kimondható, hogy a 8. cikk alkalmazandó.

A Bíróságnak ezért meg kellett vizsgálnia, hogy megfelelő egyensúlyt teremtettek-e a társaság magánélet tiszteletben tartásához füződő joga és a Bajorországi Evangélikus-Lutheránus Egyház véleménynyilvánítási szabadsága között. A Bíróság szerint az egyház képviselőjének kifogásolt nyilatkozata egy közérdekü vitához járult hozzá, nevezetesen az adatbiztonságról az egészségügyi adatok védelmének érzékeny területén, amely vita már a közzététel előtt is létezett. A kijelentések - amennyiben arra utaltak, hogy az Univerzális Élet hozzáfért a betegek adataihoz - olyan tényekre támaszkodtak, amelyeket a hazai bíróságok igaznak találtak. Az adatokkal való visszaélés veszélyére vonatkozó megjegyezés pedig értékitélet volt, amely elegendő ténybeli alappal bírt. Ami a kérelmező társaság "kétes szervezetként" való leirását illeti, e negatív értékítéletnek elegendő ténybeli alapja volt, mivel utalt arra, hogy a társaság de facto egy másik vallási közösség irányítása alatt állt, amelynek az orvosi kezelésekről vallott szokatlan nézeteit a hazai bíróságok előtt sem vitatták, és nem volt sértegető. Az pedig, hogy a társaságnak meg kellett szüntetnie üzleti tevékenységét, lényegében a mások által kezdeményezett nyilvános vita következménye volt. A német bíróságok így minden tényezőt tekintetbe vettek, és nem lépték át a mérlegelési jogkörüket a 8 . cikk tekintetében. A Bíróság ezért a kérelmet nyilvánvalóan megalapozatlannak találta. ${ }^{25}$

2.6. Kulis and Rózycki v. Poland ügy ${ }^{26} 1999$-ben a Star Foods Company nevü élelmiszergyártó cég egyik reklámkampányában az általuk gyártott chips csomagolásán egy népszerü rajzfilmfigurát - egy Reksio nevü kiskutyát - helyeztek el, amit a mellette lévő felirat szerint gyilkosnak neveztek. Erre válaszul az Angora című lengyel magazin és gyermekeknek szánt melléklete, az Angorka tulajdonosfószerkesztője megjelentetett egy cikket az Angorkában, mely utalt a Star Foods nevű vállalat által előállított burgonyaszirom reklámkampányára. A magazin első oldalán egy rajzolt fiú egy csomag Star Foods burgonyaszirmot tartott a kezében, és így szólt Reksio kutyához (egy gyermekek körében közkedvelt rajzfigurához): „Ne aggódj! Belőlem is gyilkost csinálna, ha ezt a vackot enném!" A kérdéses rajzhoz ez a címsor tartozott: „A lengyel gyermekeket megrázta a burgonyaszirom hirdetés:

sikerének és életképességének védelme a részvényesek és alkalmazottak, valamint a tágabb gazdasági haszon érdekében is.

Ugyanakkor a Bíróság megállapította, hogy az állami tulajdonú társaság által az idősek intézményi ellátásának hiányosságaira vonatkozó információkhoz való közvélemény annyira fontos egy demokratikus társadalomban, hogy felülmúlja annak érdekét a jó üzleti hírnév védelme iránt.

https://hudoc.echr.coe.int/spa\#\{"itemid":["001-105777"]\}

${ }^{25}$ Az esetet idézi még Kóczián Sándor: Az EJEB véleménynyilvánítás szabadságával kapcsolatos ítéletei, 263-265.

https://nmhh.hu/dokumentum/192028/Az_EJEB_szolasszabadsaggal_kapcsolatos_iteletei_AF.pdf (letöltés: 2021. 04. 10.)

Továbbá: https://inforrm.org/2014/10/09/case-law-strasbourg-firma-edv-fur-sie-v-germany-article-8companies-and-the-right-to-reputation-hugh-tomlinson-qc/

${ }^{26}$ Application no. 27209/03., 2009. október 6-i ítélet 
Reksio gyilkos". A következő oldalon kezdődő cikk beszámolt arról, hogy a szülőket és a gyerekeket felháborította és megrémítette, hogy a fent említett burgonyaszirom szlogenje. A társaság a hetilap kiadóját és a magazin főszerkesztőjét beperelte hírnévsértés miatt. A lengyel bíróságok megállapították a hírnévsértést. Az indokolás szerint a cikkben használt erősen pejoratív szavak - amelyek undorodást és irtózást közvetítettek - alkalmasak voltak a cég termékeinek lejáratására, amivel megsértették a társaság személyiségi jogait. A kérelmezők az EJEE 10. cikkének megsértésére hivatkoztak.

A Bíróság megállapította, hogy a gazdasági társaságnak joga van a jó hírnévhez. A kérelmezők azzal érveltek, hogy a publikáció a cég meggondolatlan és káros reklámkampányával kapcsolatos nyilvános vitához járult hozzá. A Bíróság szerint a hazai bíróságok nem vették kellően figyelembe a kérelmezők érvét, hogy a szatirikus karikatúra a szerintük elfogadhatatlan reklámkampánynak vágott vissza, és a kisgyerekeket célozta. Az ügy tárgya nem egy nem becsületsértő tényállítás, hanem egy értékitélet. A Bíróság szerint a közzététel a cég és a reklámkampány szatirikus megbélyegzésének minősült egy karikatúra formájában. A Bíróság úgy ítélte meg, hogy a kérelmezőknek nem az volt az elsődleges céljuk, hogy a chips minőségét becsméreljék, hanem hogy felhívják a figyelmet a cég által használt jelszavak típusára, és az ilyen módszerek elfogadhatatlanságára az eladások növelése érdekében. A Bíróság szerint a hazai bíróságok nem vették figyelembe azt a tényt, hogy a sajtó feladata, hogy közölje az információkat és eszméket a közérdekú ügyekben, és ennek során lehetősége van egy bizonyos fokú túlzás igénybevételére vagy akár provokációra is, más szóval némileg mértéktelen nyilatkozatokat is tehet. A kérelmezők által használt megfogalmazás túlzott volt ugyan, azonban a felperes reklámkampányában használt jelszavakra reagáltak, amely nem tanúsított sem érzékenységet, sem megértést a célba vett fogyasztók életkora és sebezhetősége, azaz a gyermekek iránt. Mindezek alapján a Bíróság megállapította az Egyezmény 10. cikkének sérelmét. ${ }^{27}$

\section{Összefoglalás}

Az EUB joggyakorlata elsősorban a jogi személy jó hírnevének megsértése esetén alkalmazandó joghatóság kérdésében előremutató, amelynek alapját a természetes személyek hasonló ügyeiben már meghozott döntések adják. Egyrészről, a kialakított joggyakorlat alkalmazható a jogi személyek esetében is, másrészről meghatározásra került, hogy mit érthetünk a jogi személy érdekeinek központja alatt. Mindezeken túl, elismerésre kerültek a jogi személyt is megillető jogok, közöttük a jó hírnévhez való jog.

\footnotetext{
${ }^{27}$ Az esetet összefoglalta még Kóczián Sándor: Az EJEB véleménynyilvánítás szabadságával kapcsolatos ítéletei, 229-231.

https://nmhh.hu/dokumentum/192028/Az_EJEB_szolasszabadsaggal_kapcsolatos_iteletei_AF.pdf (letöltés: 2021. 04. 10.), továbbá Dominika Bychawska-Siniarska: A véleménynyilvánítás szabadságának védelme az Emberi Jogok Európai Egyezménye alapján. Európa Tanács, Európa Tanács, 2018. november, $175-176$.

https://rm.coe.int/protecting-the-right-to-freedom-of-expression-under-the-europeanconve/168092f25a
} 
Az EJEB elé kerülő ügyek tekintetében látható, hogy elsősorban az EJEE 10. cikkének megsértésére hivatkozva indítják azokat, mert az adott állam a kérelmezőt marasztalta a jogi személy hírnévsértése miatt polgári, vagy büntetőjogi alapon. Kivételes az, amikor a jogi személy indított eljárást az EJEE 8. cikk alapján, jó hírneve védelmében. $A z$ EJEB által eddig tárgyalt ügyek többsége, az egyezmény természetéből fakadóan is, természetes személyeket érintett, a jogi személyekre vonatkozó esetek ezért ezen ügyek tapasztalatain alapulnak.

Számos, általános érvényű megállapítás tehető, figyelemmel azonban az e körben megmutatkozó gazdag szakirodalomra, csak néhányat emelnénk ki:

Az EJEB a 8. cikk tárgyi hatályát kitágítva, azt a jó hírnév védelmére is alkalmazza. Levonható az a következtetés is, hogy a 10 . cikk alapján védett véleménynyilvánítás szabadsága és a nemzeti állam által a jó hírnév védelme okán alkalmazott korlátozásokat mérlegre téve, annak nyelve a véleménynyilvánítás felé billent, az EJEB a hazai korlátozásokat túlzottnak ítélte, amelyek nem voltak szükségesek egy demokratikus társadalomban, tágítva a véleménynyilvánítás-szabadságának terét. 28 Az EJEB a vizsgálódásba bevonta később a 8. cikket is, a jó hírnév így közvetlenül a véleménynyilvánítás szabadságával szemben került mérlegre. Az összemérés tekintetében az EJEB számos szempontot adott meg.

Az EJEB nyomatékkal vizsgálta azt is, hogy a vélt hírnévsértés tényállítással vagy véleményközléssel történt, és megállapította az egyezmény 10 . cikkének megsértését, ha az adott állam bírósága nem tett különbséget e közlések két fajtája között, vagy azt rosszul minősítve, követelte, hogy értékítélet/vélemény valós ténybeli alapját bizonyítsák, vagy fordítva, a tényállítást nem engedte bizonyítani, mert azt véleménynek minősítette (Csánics kontra Magyarország). ${ }^{29}$

Az EJEB ítélkezési gyakorlata és a jogi személyek viszonylata vonatkozásában megállapítható, hogy az EJEB elfogadta azt, hogy az EJEE 8. cikk a jogi személyek jó hírnevét is védi.

A jogi személyeket érintő, szinte valamennyi esetben, a sértőnek vélt nyilatkozatot véleménynyilvánításnak, értékítéletnek minősítette, és kivétel nélkül megállapította, hogy a kérdéses nyilatkozatok közérdekűek, a nyilvánosság tájékoztatását szolgálták. Ez a szemlélet alapvetően meghatározta aztán az ügyek kimenetelét, a véleménynyilvánítás szabadságának engedve teret.

A nyilatkozat közérdeküvé nyilvánításának másik következménye az volt, hogy az EJEB több ügyben is kinyilvánította, a közérdekü ügyekkel kapcsolatos információk és eszmék közlése során megengedett bizonyos fokú túlzás, sőt provokáció alkalmazása, akár némileg mértéktelen nyilatkozatok megtétele. Azt is megállapította, hogy a vulgáris kifejezések használata önmagában nem perdöntő

${ }^{28}$ Hasonló következtetésre jutott Gyulay Dániel: Strasbourg helyesbít, avagy a véleménynyilvánítás szabadságának érvényesülése az Emberi Jogok Európai Bírósága döntéseiben c. tanulmányában. In: Belügyi Szemle, 2020, 3. szám 57-72.

http://real.mtak.hu/108218/1/GyulayDanielBelugyiSzemle2020.3.szam57-72..pdf

${ }^{29}$ Az EJEB mérlegelési gyakorlatáról és a tényállítás-vélemény vizsgálatáról lásd bővebben Eric Barendt: A kifejezés szabadságának és a magánszféra védelmének egyensúlya a Strasbourgi Bíróság ítélkezési gyakorlatában. In: Iustum Aequum Salutare, 2010, 3. szám, 45-69. http://ias.jak.ppke.hu/hir/ias/20103sz/06.pdf 
valamely sértő kifejezés megítélésekor, mivel az pusztán stilisztikai célokat is szolgálhat.

A jogi személy hátrányára vizsgálta továbbá a bíróság a jogi személy nyilatkozatot kiváltó magatartását, vagy egyéb körülményeit (pl. állami tulajdon), valamint a véleménynek a jogi személy reputációjára gyakorolt hatását.

Az EJEB kifejezésre juttatta, hogy különbség van egy gazdasági társaság kereskedelmi jó hírnévhez füződő érdeke, valamint az egyén - társadalmi státuszt érintő - jó hírneve között. Míg ez utóbbi hatással lehet a méltóságra, a kereskedelmi jó hírnévhez füződő érdek viszont nélkülözi ezt az erkölcsi dimenziót. Ez, a fentiekből is látható módon, oda vezetett, hogy az EJEB a vélt sértésekkel szemben, nagyobb toleranciát alkalmazva tárgyalta a jogi személyeket érintő véleményeket. 